\title{
Codification of Hungarian Private (Civil) Law in a Domestic and International Comparison
}

SuMMARY

The study analyses the centuries-old process of the codification of private law (civil law) in Hungary. The author believes that the Roman law tradition in Hungary survived at both a legislative and a theoretical level. Romanist (mainly German Pandectist) influence can be observed in various draft civil codes of the country. The first Hungarian Civil Code, promulgated in 1959 and put into effect in 1960, was a socialist-style civil code. The procedure of harmonisation with the law in Europe influenced the new (second) Hungarian Civil Code promulgated in 2013.

Keywords: civil law, codification of law, harmonization of law, Pandectist legal tradition, private law, Romanist legal tradition
ROMAN LAW AND PRIVATE LAW AS

DISCIPLINES IN THE 19TH CENTURY ${ }^{1}$

The first significant influence in Hungarian civil law, which already meant a shift towards "Europeanisation" in the modern sense of the word, was the impact of German Pandectists (Romanists, Pandect Law or the discipline of pandects), hallmarked by the name of Friedrich Carl von Savigny (Hamza, 2009; 2013). Its earliest traces are demonstrable in the work of the first great private law solicitor of the 19th century, Ignác Frank (1788-1850), who can be considered as "the trailblazer of a new era”, as László Szalay has put it, despite the fact that he consistently opposed codification. In his work entitled Specimen elaborandarum institutionum iuris civilis Hungarici, published in 1823 and still reflecting the influences of a move-

Dr IUR. DDr H.c. Gábor Hamza, University Professor, Eötvös Loránd University Budapest, full member of the Hungarian Academy of Sciences (gabor.hamza@ ajk.elte.hu). 
ment termed "rationalist natural law" (Vernunftrecht, or the "law of reason"), primarily the impacts of Christian Wolff, Ignác Frank uses the terms of Roman law to discuss Hungarian land ownership, and these terms also appear in his other works depicting Hungarian law. As demonstrated by Elemér Pólay, Ignác Frank cannot yet be considered as a representative of the Historical School of Jurisprudence (Historische Rechtsschule).

The Historical School of Jurisprudence, and more specifically, Pandectistics (Pandektenrecht or Pandektenwissenschaft) is fully manifested for the first time in the works of Gusztáv Wenzel (1818-1891), Ignác Frank's student. In his study about The System of Hungarian Private Law, he applied the system of pandects, and he was the first in Hungarian jurisprudence to explain the theory of legal relationships, legal institutions, legal facts and legal transactions on a Pandectist footing. Although Gusztáv Wenzel was clearly a Pandectist, naturally, in his works he frequently refers to Roman law.

From the second half of the 19th century, Pandectistics had an increasing impact on Hungarian jurisprudence, and thus also judicial practice, through the work of the "universal private law solicitor”, Gusztáv Szászy-Schwarz (1858-1920). As practically all of our Romanists and private law solicitors were the disciples of German Pandectists (Szászy-Schwarz and Mihály Biermann, a lecturer at the Gyôr and then at the Nagyszeben academy of law learnt from Rudolf von Jhering, while Elemér Balogh, who demonstrated outstanding merits in comparative law, attended the lectures of Heinrich Dernburg), they promoted the transposition of an increasing number of German Pandec- tist legal elements into Hungarian judicial practice through their legal writings.

\section{The Role of Roman LAW IN THE CODIFICATION OF PRIVATE LAW ${ }^{2}$}

The preparation of Hungarian ius privatum for codification was launched by Act XVIII of 1791 by commissioning a board of law (deputatio iuridica) to prepare a private law bill (Proiectum nonnullarum utilium civilium legum). This draft version, completed after two years but printed, i.e. published only decades later, in 1826 , does not reflect any impact of Roman law in either its structure or its content, and cannot be considered as a draft code in its nature. It stands to reason that the adoption of the French Code civil, considered by László Szalay as ideal, was ruled out, and as a result of the political developments, the second attempt at codification required by Act XV of 1848 also failed.

After 1853, the General Civil Code of Austria (ABGB, Österreichisches Allgemeines Bürgerliches Gesetzbuch) entered into force in Hungary and in Transylvania, and therefore a restart of codification was delayed until the Compromise. The general part (1871) of the Code of General Private Law was elaborated by Pál Hoffmann (1830-1907), a renowned legal expert in Roman law, who was a lecturer at the Pest university of sciences. It follows the parts in the 1863 Saxon Civil Code (Bürgerliches Gesetzbuch für das Königreich Sachsen), mainly influenced by Georg Friedrich Puchta (1798-1846), and practically codifying the Pandectist literature and the law of pandects.

Bálint Ökröss (1829-1889) was a member of a school that advocated the codifi- 
cation of Hungarian private law according to the pattern of rules set out in the ABGB. Both the structure and the orientation of the draft law of inheritance (1882) by István Teleszky (1836-1899) are based on the Saxon Civil Code, however, in respect of the institutions of the law of inheritance, the latter had principal regard for local Saxon law. Similarly to a recommendation traced back to Pál Hoffmann, the chapter on the law of contractual obligations (1882) drafted by István Apáthy (1829-1889), influenced by the 1866 Dresden Draft (Dresdener Entwurf), which paved the way for the subsequent BGB (the German Civil Code, or Bürgerliches Gesetzbuch), followed the (Willenstheorie) hallmarked by Friedrich Carl von Savigny in its regulation of legal transactions. The same applies to the draft General Part, compiled by Elek Gyôry (1841-1902) in 1880. The part on the law of rights in rem (1882) Endre Halmossy and the law of marriage, personal and property rights drafted by Béni Grosschmid (1852-1938) are less influenced by Pandectistics.

The idea of compiling a uniform code of private law became prevalent in 1895, when Minister of Justice Sándor Erdélyi established the committee for the preparation of a consolidated draft civil code, which included Romanist and civil law solicitor Gusztáv Szászy-Schwarz (18581920) as a member. The part on the law of inheritance was elaborated by SzászySchwarz.

The draft version prepared in 1900 with a structure and legal institutions bearing marks of the German BGB breaks with the practice of piecemeal codification. This draft consisted of four parts (personality rights, family law, the law of contractual obligations, the law of rights in rem and inheritance law) without a general part (Allgemeiner Teil), as the first titles under the law of contractual obligations have that function. The draft made in 1900 already follows the principles of declaration theory (Erklärungstheorie) in its discussion of legal transactions (Rechtsgeschäfte). The German Civil Code (Bürgerliches Gesetzbuch, BGB) had a higher impact on the next, smaller-scale private law bill compiled in 1913, although it did not contain a general part either.

The 1928 proposal for a Code of Private Law, called ratio scripta by courts, worded with the prominent involvement of Béla Szászy (1865-1931), aptly called the "Hungarian Eugen Huber", strongly reflects the influence of the Swiss Civil Code (Zivilgesetzbuch, ZGB) and the Swiss Act on the Law of Contractual Obligations (Obligationenrecht, OR). ${ }^{3}$ Although for several reasons the Draft Code of Private Law failed to become a law, in other words, it never had a vigor legis, not even despite the provisions of Act XXII of 1931, certain legal institutions included in it, thus mortgage, regulated in Act XXXV of 1927, were approved by legislation (Szladits, 1932).

After World War II, the Council of Ministers set up a codification committee in December 1953 for the elaboration of a civil code. The committee included lecturers from the civil law departments of the three faculties of law - in Budapest, Pécs and Szeged -, from the civil law department of the university of economics, staff members from the Institution of Law and Political Sciences of the Hungarian Academy of Sciences, and the representatives of the Supreme Court, the Chief Prosecutor's Office and 
the Ministry of Justice. Following several years of preparatory work, the first draft had been compiled by September 1956 . After a smaller committee established by the Minister for Justice reviewed the fundamental questions of the draft in the spring of 1957, the editors amended the draft. This draft was published and discussed. The final version, repeatedly reviewed by a committee of the Ministry of Justice was submitted to Parliament as a bill in 1959. The code was approved in 1959, and the consolidated Civil Code entered into force in Hungary on 1 May 1960. Despite its socialist key features, the Civil Code reflects the influence of the German BGB, the Swiss OR and ZGB, and the 1928 Hungarian Code of Private Law. From among socialist civil codes, the editors of the code took into consideration the Soviet-Russian code that was approved in 1922 and entered into force on 1 January 1923, the Czechoslovakian civil code adopted in 1950, the 1955 Polish bill and the Bulgarian act regulating ownership and approved in 1950.

The Civil Code approved in 1959, which remained in effect up to 15 March 2014, consisted of six parts, and the individual parts were divided into chapters. The first part contained the introductory provisions (Articles 1-7), however, this cannot be considered as a general part (Allgemeiner Teil) in a Pandectistic sense of the term. The second part contains individual rights (Articles 8-87), however, family law was regulated in a separate statutory regulation: Act IV of 1952. (The act on family law regulates the institution of custody and guardianship.) The title of the third part was "Ownership Rights" (Articles 94-197). The fourth part contains provisions of the law of contractual obli- gations (Articles 198-596). The fifth part discusses the law of inheritance (Articles 598-684), while the sixth part contains closing provisions (Articles 685-687).

The 1959 Civil Code did not follow the system of pandects (Földi, 1986). Regarding its structure, it is comparable to the system applied in Gaius's Institutio, with the fundamental difference that civil procedure and the above-mentioned family law were regulated in separate codes, and the law of inheritance was placed last. There were numerous elements of Roman law in the Civil code, which served as the fundamental source of Hungarian private law (civil law) for several decades (Földi and Szájer, 1985). The part on personality rights recognised the conditional legal capacity of foetuses, however, in contrast to Roman law, the statutory establishment of the time of conception was a rebuttable presumption. ${ }^{4}$

As a peculiar feature of the 1959 Civil Code, despite the fact that Part III is entitled Ownership Rights, for certain dogmatic considerations it regulates rights in rem, and contains numerous casuistic provisions. Among these regulations, Roman law traditions are especially clearly reflected in the provisions relating to taking the fruits of a thing or to taking possession of property that has no owner (bona vacantia). Partial titles to the various forms of ownership - the concept of uti, frui, habere, possidere and abuti-reflect the impact of Uplianus.

In relation to possessions, Hungarian law only recognised possessio civilis, and ruled out possessio naturalis. Originally, the act did not regulate possessory protection, but it was subsequently developed through judicial practice. Regarding the transfer of ownership, the Civil 
Code of 1959 followed the principle of tradition: in addition to the ownership title (causa) it also required the transfer (traditio) of the thing owned. The Hungarian regulation of adverse possession was less influenced by Roman law, as only the thing suitable for adverse possession (res habilis) was required, and good faith (bona fides) and a legal title (iustus titulus) were not. The Hungarian Civil Code considered easements as independent rights of use.

The law of contractual obligations was not divided into general and special parts, it is rather focussed on the two institutions considered fundamental: contracts and liabilities. The individual types of contracts also showed the influence of Roman law. The individual sub-types of contracts for work were reminiscent of the individual types of locatio conductio. However, in contrast to the gratuitous mandatum defined in Roman law, as under Hungarian law a mandate, an agency contract or a contract for services is onerous, as a rule of thumb.

To meet the requirements of the socialist (state socialist) economic and social order prevailing during its codification, the 1959 Civil Code gave a detailed regulation for agricultural product sales contracts, naturally unknown in Roman law, due to the level of development in production back then. Nevertheless, the essence of agricultural product sales contracts can be traced back to sale and purchase agreements not only known but meticulously elaborated in Roman law, specifically to the forms constituting the special kind of sale and purchase termed as emptio rei futurae or emptio rei speratae. The code contains a general rule on liability and allows certain excep- tions. These provisions seem more or less casuistic, and are rooted in Roman law, with the exception of liability for risk in unsafe work environments, which is naturally unknown in antique laws. Certain legal institutions under Roman law, including receptum nautarum cauponum et stabulariorum, actio de deiectis vel effusis and actio de positis vel suspensis, were actually transposed in the regulations on increased liability by hotels and restaurants and on liability for damaged to buildings (Mihály, 1959; Grzybowski, 1961; Fesztl and Tamás, 1967; Eörsi, 1974; Gabor, 1982, Vékás, 1987).

The regula Catoniana (Article 234) and the pignus Gordianum (Article 267) manifest the survival of Roman law traditions. Return to the traditions of Roman law is reflected by the Supreme Court's Civil Law Decision in Principle No. XXIV, which interprets Article 192 (2) and allows both possessory and petitory actions in property protection.

As the Hungarian law of inheritance is based on the principle of ipso iure, in contrast for example to Austrian law, it does not recognise the concept of vacant succession or hereditas iacens. In contrast, among others, to German and Austrian law, the Civil Code of 1959 expressly prohibited pupillary substitution, despite its actual origins in Roman law, and only allowed residuary legacy (Tóth, 2001; Boóc, 2002).

The Civil Code of 1959 was amended on numerous occasions. Among the amendments performed before the change of regime, the changes approved in 1967 and 1977 were especially important. In terms of Roman law traditions, the amendment enacted in 1991 is particularly notable, as it allowed the Civil Code 
to include, similarly to numerous other European private law jurisdictions, like the German, the Swiss and the most recent Dutch civil law, more specifically the new Dutch Civil Code (Nieuw Burgerlijk Wetboek), the category called "objective good faith", and provided that it must be broadly used in private law relationships as a general clause (Földi, 2001). Act XIV of 1991 deserves special mention, as it prohibits the conclusion of contracts that are in conflict with boni mores. Another example of return to the traditions of Roman law included the mortgage right codified in Act XXVI of 1996. Note that the complete legislation on mortgage by legal charge was re-regulated in Act CXXXVII of 2000 based on the current economic requirements and on the basis of the traditions of Roman law. The Civil Code is not the only body of regulations to ensure that the individual Roman law institutions survive. Other examples include Act XLIX of 1991 on bankruptcy, liquidation and dissolution procedures. Subject to a judicial approval, agreement between the parties is reminiscent of cessio bonorum in numerous cases (Hamza, 1989; 2001).

Note that the Civil Code was not the exclusive regulation of Hungarian private law (ius privatum). Family law was regulated by Act IV of 1952 on marriage, family and custody, promulgated on 6 June 1952, entered into force on 1 January 1953, and amended, in the period prior to the change of regime, in 1974 and 1986. Pursuant to the amendment adopted in 1986, the conclusion of a pre-nuptial agreement was allowed once again under Hungarian law. After regulation in a decree, labour law was regulated in an act adopted in 1967 and amended several times subsequently. In 1992 a new labour code was adopted. Copyright was regulated by an act adopted in 1969 and replaced by a new act in 1999. The provisions of international private law were included in a decreelaw adopted in $1979 .{ }^{5}$

\section{Notes}

1 For more details on this topic see also Böszörményi Nagy, 1970; Pólay, 1976; Zlinszky, 1997. About Ignác Frank see Villányi Fürst, 1935; about Gusztáv Wenzel see Balázs, 1990; about Gusztáv Szászy-Schwarz see Szladits, 1934; and about Elemér Balogh see Hamza, 1999.

2 For more details on this topic, see Dauscher, 1862; Dell'Adami, 1877; 1885; Teleszky, 1887; Meszlény, 1901; Szászy-Schwarz, 1909; Asztalos, 1970; Bernáth, 1970; Mádl, 1970; Weiss, 1970; Peschka, 1970; Csizmadia, 1974; Basa, 1996; Harmat, 1999.

3 It is highly instructive to give a brief overview of the impacts of Pandectistics on (non-fault) strict liability. The draft compiled in 1900 regulated liability in accordance with the German Civil Code (BGB), although not relying on its literal translation, based on fault. Based on the second (1887) draft of BGB (Zweiter Entwurf), Article 1486 of the 1913 draft already gave room to the principle of damages based on objective liability. The famous Article 1737 in the 1928 Code of Private Law, which regulated equitable liability, followed, although indirectly, the second draft version of BGB when it allows the subsidiary enforcement of the objective principle of liability for damages.

4 About the Roman law institutions mentioned in this study, see Földi and Hamza, 2018.

"In Hungary the codification of the new civil code began on the basis of Government Decision No. 1050/1998. (IV. 24.). The editors of the draft code also took Hungary's legal harmonisation goals into consideration. Their aim was to make the new code suitable for providing a private law regulation that meets the social and economic requirements of the 21st century. It is worth mentioning that the concept of the new civil code was published at the beginning of 2002 . 


\section{REFERENCES}

Asztalos, L. (1970): Entwicklung der ungarischen Privatrechtswissenschaft im Zeitalter des Dualismus. In: Csizmadia, A. and Kovács, K. (eds.): Die Entwicklung des Zivilrechts in Mitteleuropa 1848 1944. Akadémiai Kiadó, Budapest, pp. 21-39.

Balázs, T. (1990): Die wissenschaftliche Bedeutung von dem ersten ungarischen Pandektisten, Gusztáv Wenczel mit besonderer Rücksicht auf seine Verantwortlichkeitslehre. ANNUS 31., ELTE, Budapest.

Basa, I. (1996): A kereskedelmi jogi kártérítés hatása a magánjogi kártérítésre Magyarországon a millennium idején [The impacts of damages under commercial law on damaged under private law in Hungary during the Millennium]. Államés Jogtudomány, Vol. 3, No. 1-2, pp. 53-72.

Bernáth, Z. (1970): Besitz und Besitzschutz im Spiegel der ungarischen Rechtsgeschichte unter besonderer Berücksichtigung der Rechtsentwicklung in den letzten hundert Jahren. In: Csizmadia, A. and Kovács, K. (eds.): Die Entwicklung des Zivilrechts in Mitteleuropa 1848-1944. Akadémiai Kiadó, Budapest, pp. 209-223.

Boóc, T. (2002): Az utóöröklés a római jogban, javaslattal a jövôbeni magyar szabályozásra [Secondary inheritance in Roman law, with a proposal for a future regulation in Hungary]. Közjegyzók Közlönye, Vol. 49, No. 6, pp. 3-18.

Böszörményi Nagy, E. (1970): Das ungarische Erbrecht zur Zeit des Dualismus. In: Csizmadia, A. and Kovács, K. (eds.): Die Entwicklung des Zivilrechts in Mitteleuropa 1848-1944. Akadémiai Kiadó, Budapest, pp. 413-429.

Csizmadia, A. (1974): Ungarische zivilrechtliche Kodifikationsbestrebungen im Reformzeitalter. In: Kovács, K. (ed.): Rechtsgeschichtliche Abhandlungen VI. ELTE, Budapest.

Dauscher, A. (1862): Das ungarische Civil- und Strafrecht nach den Beschlüssen der Judex-Curial Conferenz. Verlag von Friedrich Manz, Wien.

Dell'Adami, R. (1877): Az anyagi magánjog codificatiója. A nemzeti eredet problémája [Codification of substantive private law. The quandary of national origin]. Budapest.

Dell'Adami, R. (1885): Magánjogi codificatiónk és régi jogunk I. [Our codification of private law and our old law]. Franklin Társulat, Budapest.

Eörsi, Gy. (1974): A jogfejlôdés útjai a polgári jogban [Ways of legal development in civil law]. Gazdaság-és Jogtudomány, Vol. 8, No. 1-2, pp. 13-26.
Fesztl, N. and Tamás, L. (1967): Az új gazdasági mechanizmus polgári jogi vonatkozásának néhány problémája [Certain issues in the civil law considerations of the New Economic Mechanism]. University of Pécs, Pécs.

Földi, A. and Szájer, J. (1985): Római jogi reminiszcenciák civilisztikai oktatásunkban [Roman law reminiscences in teaching civil law in Hungary]. Jogtudományi Közlöny, Vol. 40, No. 7, pp. 395-403.

Földi, A. (1986): Polgári jogunk és a római jog [Hungarian civil law and the Roman law]. Acta Facultatis Politico-Iuridicae Universitatis Scientiarum Budapestinensis, No. 28, pp. 7-26.

Földi, A. (2001): A jóhiszemúség és tisztesség elve. Intézménytörténeti vázlat a római jogtól napjainkig [The principles of good faith and integrity. An outline of the history of the institution from Roman law to date]. ELTE, Budapest.

Földi, A. and Hamza, G. (2018): A római jog története és institúciói [History and institutions of Roman law]. Eszterházy Károly University, Eger.

Gabor, F. A. (1982): Socialist Economic Reform in Progress: A New Legal Framework for Entrepreneurship in Hungary. Review of Socialist Law, Vol. 8, No. 2, pp. 153-168, https://doi. org/10.1163/187529882x00118.

Grzybowski, K. (1961): Reform of Civil Law in Hungary, Poland, and the Soviet Union. The American Journal of Comparative Law, Vol. 10, No. 3, pp. 253-265, https://doi.org/10.2307/838946.

Hamza, G. (1989): Evoluzione del sistema giuridico e riforme economiche nell'esperienza ungherese. In: Annali dell'Istituto di Studi Europei „Alcide De Gasperi”. Rome, pp. 189-195.

Hamza, G. (1999): Balogh Elemér. In: Hamza, G. (ed.): Magyar Jogtudósok I. [Hungarian legal experts]. ELTE, Budapest, pp. 137-146.

Hamza, G. (2001): Il diritto romano e lo sviluppo del diritto privato ungherese. In: Iuris vincula. Studi in onore di Mario Talamanca. Jovene, Napoli, pp. 353-364.

Hamza, G. (2009): Entstehung und Entwicklung der modernen Privatrechtsordnungen und die römischrechtliche Tradition. ELTE, Budapest.

Hamza, G. (2013): Origine e sviluppo degli ordinamenti giusprivatistici in base alla tradizione del diritto romano. Andavirra Editora, Santiago de Compostela.

Harmat, U. (1999): Ehe auf Widerruf? Der Konflikt um das Eherecht in Österreich 1918-1938. IC Sonderheft 121, Vittorio Klostermann, Frankfurt am Main. 
Mádl, F. (1970): Kodifikation des ungarischen Privat- und Handelsrechts im Zeitalter des Dualismus. In: Csizmadia, A. and Kovács, K. (eds.): Die Entwicklung des Zivilrechts in Mitteleuropa 1848 1944. Akadémiai Kiadó, Budapest, pp. 87-119.

Meszlény, A. (1901): Magánjog-politikai tanulmányok. Különös tekintettel a magyar általános polgári törvénykönyv tervezetére [Studies in private law policy. With special focus on the draft Hungarian general civil code]. Politzer Zs. és fia, Budapest.

Mihály, Z. M. (1959): The Role of Civil Law Institutions in the Management of Communist Economies: The Hungarian Experience. The American Journal of Comparative Law, Vol. 8, No. 3, pp. 310 328, https://doi.org/10.2307/837714.

Peschka, V. (1970): Theoretische Grundlagen der ungarischen Privatrechtswissenschaft im Zeitalter des Dualismus. In: Csizmadia, A. and Kovács, K. (eds.): Die Entwicklung des Zivilrechts in Mitteleuropa 1848-1944. Akadémiai Kiadó, Budapest, pp. 5-20.

Pólay, E. (1976): A pandektisztika és hatása a magyar magánjog tudományára [Pandesctistics and its impact on the discipline of Hungarian private law]. József Attila University, Szeged.

Szászy-Schwarz, G. (1909): A magánjogi törvénykönyvrôl. Tanulmányok és bírálatok [On the code of private law]. Franklin, Budapest.
Szladits, Ch. (1932): Le projet de Code Civil Hongrois. Acta Juris Hungarici, Vol. 1, No. 3-4, pp. 213-221.

Szladits, K. (1934): Magyar jogászegyleti értekezések [Treatises by the society of Hungarian lawyers]. Kecskeméti Hírlapkiadó- és Nyomda Rt., Kecskemét.

Teleszky, I. (1887): Entwurf des ungarischen Erbrechts. Légrády Testvérek, Budapest.

Tóth, Á. (2001): Az utóöröklésrôl [About secondary inheritance]. Közjegyzôk Közlönye, Vol. 48, No. 5, pp. 3-15.

Villányi Fürst, L. (1935): Jogi professzorok emlékezete [The memory of professors of law]. Budapest.

Vékás, L. (1987): Zivilrecht. In: Grothusen, K. D. (ed.): Südosteuropa-Handbuch. Bd. 5. Ungarn. Göttingen, pp. 250-263.

Weiss, E. (1970): Die Entwicklung des Vertragsrechts im Lichte der ungarischen zivilrechtlichen Kodifikationsarbeiten. In: Csizmadia, A. and Kovács, K. (eds.): Die Entwicklung des Zivilrechts in Mitteleuropa 1848-1944. Akadémiai Kiadó, Budapest, pp. 285- 298.

Zlinszky, J. (1997): Wissenschaft und Gerichtsbarkeit. Quellen und Literatur der Privatrechtsgeschichte Ungarns im 19. Jahrhundert. Vittorio Klostermann, Frankfurt am Main. 